This article has been scanned by iThenticat No plagiarism detected

Volume 3, Issue 6, December 2021

p. $62-73$

\title{
SCHOOL VIOLENCE DIRECTED AT CHILDREN OF CHILD-FRIENDLY PRIMARY SCHOOLS FROM THE POINT OF VIEW OF PARENTS IN LIGHT OF THE CORONA PANDEMIC (A COMPARATIVE STUDY)
}

http://dx.doi.org/10.47832/2757-5403.6-3.5

Abdulkareem Mohsen Mohammed AL-MASTAFAOYI 1

\begin{abstract}
:
The current research aims to:

- Knowing the level of violence that primary school students are exposed to, by their teachers.

- Knowing the differences in the level of violence experienced by pupils of child-friendly primary schools and their peers in other public school

- Knowing the relationship between academic achievement and the level of violence among primary school students.

The research community includes child-friendly schools in Baghdad / Al-Rusafa, which are (107) and distributed among their general directorates of education. The research sample was randomly selected from the parents of the sixth grade students in a random way, and they numbered (80) guardians (students) by (40) males and (40) females)) divided equally by gender between child-friendly schools and regular schools. In the current research, the researcher adopted the (School Violence) Scale prepared by (Mohammed et al. 2014).

To identify the level of school violence, the t-test was used for one sample, and it became clear that the difference between the two means is not statistically significant at the significance level (0.05).

The t-test was used for two independent samples which indicates that there are no differences statistically significant for the school type variable.

To identify the relationship between school violence and academic achievement among primary students, there was no statistical significance for the t-value of the correlation coefficient between school violence and academic achievement .
\end{abstract}

Key words: Corona, School Violence, Primary Schools.

\footnotetext{
${ }^{1}$ Dr. , Iraq, abdulkareemmohseen@gmail.com, https://orcid.org/0000-0002-0479-4982
}

Copyright $\odot$ Published by IJHER Journal, www.ijherjournal.com Rimar Academy, Fatih, Istanbul, 34093 Turkey

All rights reserved

Published: 01/12/2021 


\section{Chapter One: The research problem and its importance}

The school is one of the most important social environments that affect the child after the family. It may often be the most important influence in the child's life, especially in the case of broken and poor families, especially when faced with an environment similar to the family environment from which he aspired to get out, and he feels great frustration that is reflected in his behavior in the future. Which would have the biggest imprint in human life and the method of punishment followed by the school environment may generate deviation on the long level.

The learner acquires during his interaction with the school environment many behaviors during the modeling and social education process, including the behavior of violence, and instead of the school being repelling violent behavior, it may be an incubator for it, and violent behavior may be issued by some teachers consciously or unconsciously, and it is certain that the school is not the only responsible for the spread of these behavioral manifestations, and it must play its role in confronting it and preventing its exacerbation by investigating everything that would provide the environment and the atmosphere conducive to its appearance. Many individuals in general and teachers in particular practice different methods of violence due to their lack of awareness of the extent of its danger and some believe it is the best method for educating the student, although it actually reflects a state of reincarnation of models in the home and the local community, as well as the models presented by the media. Violence has become a product of school and psychological pressures that the student suffers from, and violence is one of the problems that educational institutions suffer from, which indicates the existence of a problem that has repercussions and effects on society (Al-Qabbanji 2000:7).

Numerous research and studies conducted on violence have shown that many children acquire and apply one or more forms of violence. The (Brand) study found that children practice specific behaviors that they have previously learned from their teachers in order to match and correspond with the behavior of their teachers (Fadil Delio et al. 1999: 77). While the study (Al-Batish 1990) showed that $70 \%$ of teachers practice some form of physical violence against their students (Al-Batish, 1990:160), which results in violence against children in schools, a set of psychological and social effects, such as aggression, anti-social withdrawal, and disrespect for their teachers followed by leaving the school. So the results will be companied by negative effects on the child and society.

The current study attempts to answer a set of questions about school violence, especially in light of the spread of the Corona Pandemic and the disruption of attendance in schools for different periods, and sometimes relying on e-learning or integrated education at other times. Most of Iraq's students spent their academic year working one day a week, or two days at the best of times. This new situation has resulted in several considerations, including that the number of students has been divided into groups that do not exceed 15 students within one class and at distances determined by the conditions of social distancing set by the Ministry of Health and the Crisis Cell to confront Covid 19.

Many studies, before the emergence of the Corona Pandemic, diagnosed an increase in the rate of school violence, which some school administrations and educational faculties still adopt as a means of discipline. And it may start with physical violence to reach verbal or moral violence in the absence of awareness of the teacher and his lack of appreciation for the results and effects of this violence and his conviction that hitting and punishment is the only way to discipline students and get them to exercise diligence and discipline. When examining the phenomenon of violence in schools, it is noted that students are exposed to many problems that prevent them from adapting to the school environment, including what is related to the teacher or the teacher and his use of one of the methods of violence and severity such as cruelty, beating and ridicule of the violating or negligent student, in addition to what schools are suffering at the present time. From the modest capabilities and 
crowding of classes and overcrowding with learners, which affects his performance in delivering the study material to the large number of them, and his inability to provide some appropriate time to take care of students with low academic achievement, all of this leads to the emergence of cases of constant friction, which generates tension for the teacher and the learner Both, which results in the teacher resorting to cruelty to the learner. (Mohammed et al, 2014:2 2). (Al-Helou and Assaf, 1998) stressed that the most important problems that the student suffers from are the emotional and psychological aspects, such as anxiety, tension and lack of security, due to motivating conditions and fear of beatings, insults and mockery of them by their teachers, in addition to the disorder of the students' psychological state, and poor compatibility Frustration and indifference in preparing lessons, and perhaps the most dangerous type of school violence is the harsh treatment of students, as many of them are subjected to mistreatment and deliberate neglect by their parents or those responsible for their upbringing, under the pretext of disciplining them, or as a catalyst for a nervous state or emotional agitation of which the child is a victim. Abuse between beatings leads to deprivation of the necessary needs, as well as the suffering and bad psychological and academic effects that this treatment generates, which may lead to providing society with abnormal children. (Al-Helou and Assaf, 1998:68)

As other studies have shown, children learn violence through parental punishment. Through the researcher's experience as a member of the Permanent Committee for Guidance in the Ministry of Education, and through continuous visits to schools, whether in the city of Baghdad or in the provinces, and by examining the work of educational counselors, he found that many students exposed to violence, whether by teachers or by their colleagues . The phenomenon of violence and aggression that occurs in schools is a serious phenomenon that many educational institutions suffer from in many countries, and it has become a fertile field for research and study by those in charge of the educational sector in particular, so it requires concerted joint efforts, both at the level of government educational institutions or community organizations Civil society, because it is a social phenomenon in the first place and its negative repercussions affect the entire society, and it is necessary to deal with caution and professionally and study the problem in a real study, and to know the environmental conditions surrounding all the student, he may have a broken family behind him, because of the loss of the head of the family or because of difficult social or economic conditions or The separation of the parents, and there may be a family that takes care of him and pampers him, his requests are orders and his actions are acceptable, and in the end the child is a victim of those methods of dealing and education, which highlights the need to take his hand, and the school must provide him with guidance and educational guidance, and work to modify and correct his behavior, Paying attention to his future trends, through a healthy school atmosphere, so that he can become a compatible student, who can benefit from the educational activities offered (Mohammed et al., 2014:8)

Violence in children is one of the problems that has increased in prevalence in the last decade, due to the increase in the number of students and the lack of schools that are not commensurate with the steady increase in school enrollment, as well as other factors, including the lack of an appropriate descriptive school climate that satisfies his psychological needs School violence is not limited to what occurs by the teacher to the student, but it extends to other forms represented in the student's violence against the teacher, the school administration's violence against the student, the student's violence against the administration, the students' violence against each other, and their violence against school property.

The researcher believes that the increase in scenes of violence in the past years through pictures and films of terrorist bombings or pictures of domestic violence and suicide cases, and cross-violence during the demonstrations that swept the country and intensified during 
the last three years, had an impact on acquiring and learning violence among this segment of society.

Several studies have shown that the spread of electronic games that stimulate aggression, as well as watching police and violent films, are among the reasons contributing to the acquisition of violent behavior. (Ibrahim, 1988: 53)

The Ministry of Education has long been aware of the phenomenon of school violence in all its forms, and has taken many measures, including: Issuing educational systems that include educational texts and values that oblige teachers and educational groups to follow them and communicate those values to learners by educational methods, and to stay away from everything that offends them, as it issued instructions strict measures to prevent school violence, for example, uncles No. 2794 on 3/4/2013, especially beatings and any form of cruelty and humiliation, and everything that offends the psyche of these learners, and the Ministry has reconsidered the school curricula, and included moral values and methods of guidance and spreading a spirit of tolerance and treatment Learners' behavior in the correct educational methods, the formation of a human rights unit in the General Directorate of Curricula, and the signing of the Human Rights Regulations issued by the United Nations in 1989 and the Convention on the Rights of the Child in 1990 that Iraq ratified in 1994.

The Ministry also stressed on several occasions the importance of using positive discipline methods as an alternative to methods of physical or moral punishment, and for this purpose it held many conferences and workshops, and hosted many educators and specialists in this field.

The importance of this study is reflected in studying the level of violence that students are exposed to from the point of view of parents and in light of the outbreak of the new Corona epidemic, as well as comparing a sample of child-friendly schools and other schools to know the level of school violence in each of them, and because violence directed at students by teachers is considered One of the types of violence that a student is exposed to within the school. It is also a scientific attempt to contribute to providing the educational institution with research and studies for one of the important variables, as school violence is a factor and a variable that seriously and clearly affects the educational process and the relationship of teachers with students and their acquisition of various study and educational skills, and their preparation for future practical life.

\section{Second: Research objectives}

1- Knowing the level of violence that primary school students are exposed to, by their teachers.

2- Knowing the differences in the level of violence experienced by pupils of child-friendly primary schools and their peers in other public schools.

3- Knowing the relationship between academic achievement and the level of violence among primary school students.

\section{Third: Research limits}

The current study is limited to child-friendly primary schools and other public schools in the General Directorates of Education in the Baghdad / Rusafa governorate for the academic year 2020/2021 AD. 


\section{Fourth: Defining terms}

\section{Violence}

\section{- Definition (Matouk 1993)}

It is a behavior based on suppressing minds and souls, not on suppressing the bodies by beating, kicking or torturing.

\section{Definition (David 2003)}

All practices and methods directed towards others without real will and with the provision of harm (Hassan, 2012: 2).

- Definition (Maghazi 1993): A cultural term, what is considered violence in one culture may not be considered so in another culture. Al-Maghazi (1993: 32 .)

- Definition (Al-Shayji: 2002) violence is a form of human aggression that is intended to harm oneself, harm others and destroy property, and that violent behavior is characterized by repetition. (Al-Shaiji 2002: 2 2)

The researcher defines school violence as: any physical or moral harm or harm to which the student or his private possessions are exposed by the school administration, the teacher or other students.

Procedural definition of school violence: The degree to which the respondent obtains as a result of his answers to the items of the scale used in this research.

\section{Child-friendly schools}

Schools that aim to provide a school environment (attractive, friendly, healthy, safe) that respects diversity, difference and non-discrimination, in which students are able to express their opinions and participate effectively in the learning process, and ensure the quality of education. (Committee in the Ministry of Education 2013)

\section{Corona pandemic}

It is also called Covid 19, which the name is given by the World Health Organization to the virus that causes severe pneumonia, known as Corona, and which the World Health Organization has declared a global pandemic.

https:// help.unhcr.org/Iraq/coronavirus/covid-19-resources

\section{Chapter II:}

\section{- Theoretical framework}

The theory of social exchange. The roots of this school go back to the intellectual doctrines in economics, anthropology and psychology, and its most prominent pioneers are: (Peter Blau - George Homans - Malinowski - Skinner) that this school can explain all patterns of social relations and social behavior of individuals and groups (Al-Hassan 1999, p. A person performs aggressive behavior against another person, so the result must be similar aggressive behavior (Amer 1997: p. 17) and violence can be directed against the social institution, whether it is a family, a school, an economic or social institution, or even against society (Abbas, : 61). The counter behavior is a response to violence which is practiced by the institutions of society against the individual embodied in the penalties and controls.

And George Homans believes, that if the activity is accompanied by a reward, the individual will repeat his activity in the hope of "getting more rewards, and these rewards are what strengthen social relations and Skinner agrees with him in this view, the pioneer of the behavioral school in psychology Skinner (Al-Shweiki without his age, : 78). 


\section{Symbolic interaction theory}

Symbolic interaction is that activity through which people interpret each other's actions, behaviors and gestures on the basis of the meaning that this interpretation adds to those actions. Notable pioneers were George Hubert Mead, John Dewey, George Herbert Willemmer, Charles Cooley, and Lucy Ryan Mills.

This school believes that the behavior of the individual and groups is nothing but the embodiment of the symbols that the individual sees and is directly affected by them, negatively or positively, and that cognitive processes play a key role in the emergence of aggressive behavior among individuals.

\section{Previous studies- Arabic study}

\section{- Mustafa's study 1991}

(The impact of school violence on the degree of anxiety of students and their school adaptation)

The researcher believes that the term school violence is an old term, and the society has realized the seriousness and gravity of this problem in recent years, which has added new elements to the awareness of society and public education. The researcher adds that school violence is a continuation of family and community violence. The psychological accompaniments of violence are more destructive than violence itself, because it is an attack on the feelings of children. The study seeks to achieve a set of objectives: -

1- Investigating the impact of school violence and academic level on psychological anxiety.

2- Investigating the impact of school violence, gender and academic level on school adaptation.

In order to achieve the objectives of the study, the researcher chose a sample consisting of 245 male and female students from the seventh and eighth grades, he chose them in a random way, and he identified the names of the students who were subjected to violence and who were not exposed by the school principals and counselors, he chose (125) who were not exposed and the same of them who were exposed.

To achieve the objectives of the research and to analyze and interpret the results, the researcher used the school violence scale, the statistical treatment. The triple variance analysis was adopted to know the impact of school violence (exposed

on-exposed to violence), gender and academic level in anxiety and school adaptation, as the analysis of variance was used twice and the significance level was divided 0.05 by (2) Thus, the conditions are statistically significant at the 0.025 level.

At the end of his study, the researcher reached a number of conclusions, the most important of which are:-

1- With regard to the impact of school violence, gender and academic level on anxiety, it was found that students who were exposed to violence were more anxious than those who were not, and that females were more anxious than males, and there were no

differences between seventh and eighth grade students in the degree of their feelings of anxiety.

2- As for the impact of school violence, gender, and academic level on school adaptation, it became clear that the group that was not exposed to it, as well as the absence of differences between females and males in the academic level, and there were no differences between the seventh and eighth graders in the degree of their feeling of adaptation and did not indicate Study to any recommendations for the purpose of benefit.

The researcher believes that this study sheds light on the impact of violence on the level of anxiety among students, especially among girls. As for the current study, it attempts to 
identify violence and its level in two educational communities, child-friendly schools and regular schools, and its relationship to their academic achievement (Al-Batsh, 1991:239)

Foreign study:

- Study "(Karen Slovak 1998) tagged (mental health and the importance of detecting violence)

This study dealt with mental health and its impact on detecting violence in young people and the role of violence in society and its relationship to anxiety. The sample consisted of (549) students from the seventh and eighth grades, whose statements were recorded in the experiences of violence that they were exposed to in the present and in the past at home and at school, whether they were victims Or viewers, and the scale (trauma symptoms) was applied to them. At the end of her study, the researcher reached a number of results, the most important of which are:

1- A large percentage of boys were subjected to violence, whether they were victims or spectators.

2- Lower grade students were more exposed to violence than students upper classes.

3- The home comes first as a place of violence, then the school.

4- Violence generates a state of anxiety, anger, emotion, depression and irritability resulting from violence, whose manifestations are heartbeats and a feeling of helplessness. (Karen Slovak 1998 : 37)

This study is similar to the current study in that it tried to reveal the level of violence in the research community, as well as it tried to identify the violence that seventh grade students are exposed to, which corresponds to the first intermediate grade or seventh grade in basic schools in our educational system, with mental health that enjoys It has these students.

\section{Chapter III}

\section{Research procedures}

This chapter includes a description of the procedures that were adopted to achieve the objectives of the research, starting with defining the research community, selecting an appropriate sample, describing its characteristics, choosing the research tool to achieve its objectives, and processing its data by appropriate statistical means.

\section{Research Community}

The research community includes child-friendly schools in Baghdad / Al-Rusafa governorate, which are (107) and distributed among their general directorates of education, as shown in table (1).

Table (1): Number of child-friendly schools (study community) distributed among the General Directorates of Education in Baghdad

\begin{tabular}{|l|l|}
\hline General Directorates of Education & Number of Kid-friendly schools \\
\hline Al-Rasafa alawla & 37 \\
\hline Al-Rasafa althania & 35 \\
\hline Al-Rasafa althaltha & 35 \\
\hline Sum & 107 \\
\hline
\end{tabular}




\section{The Research Sample}

A sample of child-friendly schools and other public schools in the General Directorates of Education in Baghdad were selected as follows:

Table (2): The number of child-friendly schools (the study sample) distributed among the General Directorates of Education in Baghdad

\begin{tabular}{|l|l|l|l|}
\hline $\begin{array}{l}\text { Directorates of } \\
\text { Education }\end{array}$ & $\begin{array}{l}\text { Number of child- } \\
\text { friendly schools } \\
\text { schools of public }\end{array}$ & Sum \\
\hline Al-Rasafa alawla & 2 & 2 & 4 \\
\hline Al-Rasafa althania & 2 & 2 & 4 \\
\hline Al-Rasafa althaltha & 1 & 1 & 2 \\
\hline Sum & 5 & 5 & 10 \\
\hline
\end{tabular}

\section{Research Community:}

The research community consists of the parents of primary school students in the Baghdad Education Directorates / Al-Rusafa 1-2-3 for the academic year 201420-2021.

\section{The Research Sample:}

The research sample was randomly selected from the parents of the sixth grade students in a random way, and they numbered (80) guardians ((students) by (40) males and (40) females)) divided equally by gender between child-friendly schools and regular schools.

\section{Research Tool}

In the current research, the researcher adopted the (School Violence) Scale prepared by (Mohammed et al. 2014) The scale consists of (14) items that measure the extent of the child's exposure to violence by the teacher, knowing that the scale alternatives are (very agree, agree, disagree) and weights were given: three for the first alternative, two for the second alternative, and one for the third alternative. The respondent gets it is 42 and the lowest score is 14 .

\section{The apparent validity of the scale Face Validity}

Apparent validity is the general aspect of the measurement, and it indicates the apparent ability of the measure to measure what it was designed for. This type of honesty was confirmed by presenting the paragraphs of the school violence scale to a group of (6) expert arbitrators in education and psychology, and Appendix No. (1) illustrates this. Since the validity was achieved by $80 \%$ or more, and this indicates that the items of the scale are true, and therefore all items of the scale were accepted.

\section{Scale Stability: Reliability Coefficient}

\section{Half-Segmentation Method:}

It is one of the most widely used methods in psychological research, and it depends mainly on dividing the scale items into two parts, and calculating the correlation coefficient between 
individuals' answers to these two sections. Al-Zobaie et al., 1981, p. 32). The researcher calculated the correlation coefficient between the scores of individual and pair sequences for the members of the research sample, which amounted to $(80)$ forms on the (school violence scale), and the reliability coefficient reached $(0.71)$ by the split-half method. To correct the correlation coefficient it was $(0.81)$.

\section{The final application}

After completing the measurement procedures and verifying its validity and reliability. The researcher applied it in its final form, Annex (2), to the study sample, which amounted to (80) of parents of a student from the Directorates of Education in Baghdad, Al-Rusafa, and Table (1) illustrates this.

\section{Statistical means:}

The researcher used SPSS to reach the research results.

\section{The fourth chapter}

This chapter includes a presentation of the results of the current research, according to its objectives:

The first goal: "to identify the level of school violence to which primary school students are exposed "By comparing this mean with the hypothetical mean of the scale (28), it turns out that it is smaller than the hypothetical average, and to test the significance of this difference statistically, the t-test was used for one sample, and it became clear that the difference between the two means is not statistically significant at the significance level (0.05) and the degree of freedom (79). ) and Table (1) illustrates this.

Table (3)

The t-test for the significance of the difference between the hypothetical mean and the SMA for parents of students on the school violence scale

\begin{tabular}{|c|c|c|c|c|c|c|c|}
\hline $\begin{array}{l}\text { The } \\
\text { Sample }\end{array}$ & SMA & $\begin{array}{l}\text { standard } \\
\text { deviation }\end{array}$ & $\begin{array}{l}\text { hypothetical } \\
\text { mean }\end{array}$ & $\begin{array}{l}\text { Calculated } \\
\text { T-value }\end{array}$ & $\begin{array}{l}\text { Scheduled } \\
\text { T-Value }\end{array}$ & $\begin{array}{l}\text { Indication } \\
\text { level }\end{array}$ & $\begin{array}{l}\text { Statistical } \\
\text { significance }\end{array}$ \\
\hline 80 & 27.3 & 8 & 28 & 0.77 & 2 & 0,05 & Nonfunctional \\
\hline
\end{tabular}

The second objective: to identify the significance of the differences in school violence according to a variable school type (Child Friendly - Regular) for parents of primary school students. For the purpose of achieving this goal, the SMA of friendly schools was extracted, which amounted to $(27,5)$ and with a standard deviation of $(6.9)$, and the SMA of normal schools was $(27,16)$ and a standard deviation $(5.8)$, and to find out the significance of the differences between the two averages, the t-test was used for two independent samples. The calculated T-value amounted to (0.18), which is less than the tabular amount of 2 at the significance level (0.05), which indicates that there are no differences statistically significant for the school type variable, and Table (4) shows this. 


\begin{tabular}{|c|c|c|c|c|c|c|c|c|}
\hline $\begin{array}{l}\text { The } \\
\text { Sample }\end{array}$ & $\begin{array}{l}\text { SMA } \\
\text { For kid- } \\
\text { friendly } \\
\text { schools }\end{array}$ & $\begin{array}{l}\text { standar } \\
\text { d } \\
\text { deviatio } \\
\mathrm{n}\end{array}$ & $\begin{array}{l}\text { SMA } \\
\text { For } \\
\text { public } \\
\text { schools }\end{array}$ & $\begin{array}{l}\text { standar } \\
\text { d } \\
\text { deviatio } \\
\mathrm{n}\end{array}$ & $\begin{array}{l}\text { Calculate } \\
\text { d T-Value }\end{array}$ & $\begin{array}{l}\text { Schedule } \\
\text { d } \\
\text { T-Value }\end{array}$ & $\begin{array}{l}\text { Indicatio } \\
\mathrm{n} \\
\text { Level }\end{array}$ & $\begin{array}{l}\text { Statistical } \\
\text { significance }\end{array}$ \\
\hline 80 & 27.5 & 6.9 & 27.16 & 5.8 & 0.18 & 2 & 0.05 & Nonfunctional \\
\hline
\end{tabular}

The third objective: to identify the relationship between school violence and academic achievement among primary students.

To identify the nature of the relationship between school violence and academic achievement among primary students. The researcher extracted the Pearson correlation coefficients between school violence and academic achievement, and used the t-test to identify the significance of the correlation coefficients according to the type of school (child-friendly normal) and the results of the statistical analysis were as follows:

There was no statistical significance for the t-value of the correlation coefficient between school violence and academic achievement, as the calculated t-value for the first was 1.33 and the second, 0.193, was less than the tabular value of 1.96 at the significance level of 0.05 and the degree of freedom of 78 , and Table (3) illustrates this.

Table (5) the $t$ value of the correlation coefficients between school violence and academic achievement among primary students

\begin{tabular}{|l|l|l|l|l|}
\hline Sex & $\begin{array}{l}\text { the } \\
\text { number }\end{array}$ & $\begin{array}{l}\text { Correlation coefficient } \\
\text { between school violence } \\
\text { and academic achievement }\end{array}$ & $\begin{array}{l}\text { Calculated } \\
\text { T-value }\end{array}$ & $\begin{array}{l}\text { Statistical } \\
\text { significance at } \\
0.05 \text { or less }\end{array}$ \\
\hline Male & 40 & 0.133 & 1,19 & Nonfunctional \\
\hline Female & 40 & 0.193 & 1,13 & Nonfunctional \\
\hline
\end{tabular}

* The tabular t-value is 1.96 at a significance level of 0.05 and a degree of freedom of 79

\section{Chapter V \\ Conclusions}

1. The results showed that there are statistically significant differences between the hypothetical average and the arithmetic average on the school violence scale. That is, primary school students are exposed to violence by teachers.

2 . The results of the t-test did not appear to indicate the difference between the hypothetical mean and the arithmetic mean according to the variable of the type of school. This may be because teachers in CFS do not differ in terms of preparation, skills, or social mindset from their peers in other regular schools.

3. The results of the t-value of the correlation coefficients between school violence and academic achievement did not appear. 


\section{Recommendations}

In light of the research results, the researcher recommends the following:

1. Conducting training workshops for teachers on positive discipline methods.

2. Take firmer action with teachers who perpetrate violence against students.

3. Paying attention to physical education and art education and giving them the utmost importance because of their great impact in strengthening the relationship between the student and the teacher and between the students themselves.

4. Providing extra-curricular social, educational and recreational programs and activities that contribute to students' acquisition of social values and skills and reduce violent behavior and counter-violence.

\section{Suggestions:}

1- Conducting a study targeting school violence and its relationship to other variables such as the cultural and social level of parents.

2- Conducting a study to identify the difference in the level of school violence according to the variable of the school stage (primary - middle - preparatory).

3- Conducting a comparative study between schoolchildren in urban and rural areas.

4- Conducting a study aimed at building a counseling program to reduce violent behavior among teachers and students alike.

5- Conducting a study to identify violence among adolescent girls in primary schools.

6- Conducting a study to identify the violence that teachers and teachers are exposed to by students, students and parents.

\section{Sources:}

Ibrahim, Abdul Sattar, Clinical Psychology, Dar Al-Marikh Publishing, 1988.

Al-Batsh, Muhammad Walid, Attitudes towards corporal punishment and its practice in the Jordanian School, Educational Sciences Studies, University of Jordan, Jordan, 1991.

Al-Rousan, Farouk: The Psychology of Extraordinary Children, Amman, Dar Al-Fikr for Printing, Publishing and Distribution, 1998, p. 39.

Al-Helou, Assaf and Al-Assaf, Abd (1995) The effect of the intifada on the psychological state of the third year secondary students and its repercussions on the general educational situation in the West Bank, Gaza

Al-Hassan, Ihsan Muhammad and Dr. Abdel Moneim Al-Hassani: Social Research Methods Mosul - Dar Al-Kutub for Printing and Publishing - 1982

Jaradat, Izzat (1982): Raising the Child in Islam, Risalat Al-Ilm Magazine, a special issue on the occasion of the fifteenth century AH, Ministry of Education, Amman.

Hassan, Karima Jassem, "School violence and its relationship to the academic achievement of primary school students", The Open Educational College, unpublished research, 2012.

Muhammad, Abdul Karim Mohsen and others, "A comparative study on violence in childfriendly schools that are included in educational guidance and not included from the point of view of school principals" Baghdad, 2014.

Abbas, Mudar Taha: Religious commitment, social affiliation and hostility among perpetrators of violent crimes and their ordinary readers - PhD thesis in Psychology - College of Arts - University of Baghdad - 1997

Ali Al-Shweiki: School, Education, and Classroom Management - Beirut - Al-Hayat Library without a year of publication. 
Al-Qabbanji, Aladdin (Psychological Violence and Therapy) Al-Nabaa Magazine - July (2000).- Al-Nouri, Qais (1989): Childhood social care, obstacles, suggestions, ambition, proceedings of the scientific symposium on child care, Child Welfare Authority, Ministry of Labor and Social Affairs.

Slovak, Karan Lynne, the mental health consequences of violence Exposure an Exploration of youth in Rural setting (Rural communities), Prentice Hall, New York - 1998. 